\title{
REQUIREMENTS OF APPLICATION AND SPHERE OF APPLICABILITY OF THE CISG
}

\author{
Peter Schlechtriem*
}

\begin{abstract}
Professor Schlechtriem begins by suggesting the success of the Convention on the International Sale of Goods can be explained by its simplicity. In this paper, however, he goes on to explain and expand on some of the complexities of interpretation of the Convention, especially those in part one caused by difficulties created by reservations. However, his paper ends by suggesting that, despite the complexities, the CSIG often remains far preferable to the use of national law that may itself be uncertain or even unknown.
\end{abstract}

The Convention on the International Sale of Goods (CISG) has become an unexpected success story. It was concluded after more than 30 years preparation in 1980 by a United Nations (UN) conference in Vienna, at which 62 member-states participated. The number of states that have enacted the CISG now stands at 65 , among them all important trading nations except the United Kingdom and Japan. There are now more than 2000 decisions of state courts and arbitration tribunals reported - and probably many more that are not recorded in one of the many databases - in national law journals or court reporters. The basic structures of the CISG have influenced domestic law reforms, regional projects of harmonisation of law such as Directives of the European Community, ${ }^{1}$ and international projects of unification such as the Principles for International Commercial Contracts of 1994/2004, promulgated by the Institute for the Unification of Private Law in Rome. ${ }^{2}$ It, most likely, is the uniform law convention with the greatest influence on the law

* Dr iur (Freiburg im Breisgau), MCL (University of Chicago), Dr hc (Basel), Dr hc (Tartu), Professor Emeritus, University of Freiburg im Breisgau.

1 Directive 1999/44/EC of the European Parliament and the Council of 25 May 1999 on certain aspects of the sale of consumer goods and associated guarantees [1999] OJ L171/12.

2 UNIDROIT (ed) Principles of International Commercial Contracts (Rome, 1994/2004); text available in Peter Schlechtriem and Ingeborg Schwenzer Commentary on the UN Convention on the International Sale of Goods (CISG) (2 ed, Oxford University Press, Oxford, 2005) Appendix V; for case law and literature see $<$ http://www.unilex.info $>$ (last accessed 10 November 2005). 
of worldwide transborder commerce, and in some countries lawyers and courts are today as familiar with the Convention as they are with their domestic law - it is the lingua franca of sales.

Part of the success is or might be due to the simple requirements of application of the Convention, encoded in articles 1 to 6 , which have become a model followed in other international conventions or draft conventions. They are simple in their basic structure, although not without some tricky details which require explanation. These application requirements will be the topic of this short introduction to the Convention.

\section{BASIC REQUIREMENTS FOR APPLICATION}

\section{A Parties in Different Contracting States}

Article 1(1)(a) CISG requires only that the parties have their places of business in different contracting states, that is states which have enacted the Convention. With 65 contracting states, now many sales contracts of New Zealand traders with foreign parties (for example in Australia, Asia, the United States or Europe) are governed by the Convention.

Neither the nationality of the parties nor their qualification as merchants influences the application of the Convention, ${ }^{3}$ although consumer purchases are almost always excluded from the Convention. ${ }^{4}$ The parties' places of business in different states are, in other words, decisive, so that a New Zealand firm, having its relevant place of business in Australia, ${ }^{5}$ when concluding a contract with a firm in Wellington, might find its contract governed by the CISG.

Also, the contract must be a "sale of goods", which normally does not pose problems, but there are borderline cases, with which I shall deal later, and an important extension to mixed contracts under article 3(2) of the CISG.

\section{B Parties in Different States}

The predecessors of the CISG, ${ }^{6}$ the so-called Hague Sales Laws of 1964 - which were ratified by only nine states - used as the main requirement for application only that the parties were residing in different states, thus making it possible that parties from different states, which had not enacted the Uniform Sales Law, might have found their contract governed by this uniform law alien to both of them and to their countries. Therefore, this imperialistic claim of the old uniform sales laws was rejected in the preparation of the UN sales law, but not entirely. Article 1(1)(b) states that the CISG

3 United Nations Convention on Contracts for the International Sale of Goods (11 April 1980) 1489 UNTS 3, art 1(3) (CISG).

4 CISG, above n 3, art 2(a)

5 See CISG, above $\mathrm{n}$ 3, art 10 as to the relevant place in the case of several places of business.

6 Uniform Law on the International Sale of Goods (1 July 1964) 834 UNTS 171; Uniform Law on the Formation of Contracts for the International Sale of Goods (1 July 1964) 834 UNTS 169. 
is applicable, if the parties are situated in different states - which need not be contracting states, if the conflict of law rules of the forum lead to the application of the law of a contracting state. Thus, if there is a contract between a Japanese and an English trader subject - on account of a clause in the contract - to arbitration in Wellington under New Zealand law, the CISG would govern as the applicable law of New Zealand. This is not a very likely situation. More likely is a contract between a New Zealand trader and a Japanese or United Kingdom trader being litigated in a New Zealand court on account of a jurisdiction clause, or New Zealand law being applicable on account of a choice of law clause, or because of the conflict of law rules of the New Zealand forum, on account of objective factors determining New Zealand law to be applicable. Comparable cases had to be decided in Germany very often in the years before Germany had ratified the CISG but other European states such as Italy or France had already ratified the Convention. If their law was applicable, German courts had to apply and did apply the CISG as part of the applicable Italian or French law, ${ }^{7}$ deciding that neither the Italian nor French domestic law was applicable, but the law for international sales, that is the CISG. ${ }^{8}$ In my example of a contract between a New Zealand and a Japanese trader, even a Japanese court would have to apply the CISG, if its conflict of law rules pointed to the application of New Zealand law.

The consequence of article 1(1)(b), which meant that parties in non-contracting states could be subject to the application of the CISG, (a law that their country had not ratified), met with serious objections in Vienna, and it was accepted only on account of a compromise allowing a reservation, ${ }^{9}$ that is a ratifying state could declare that it would not be bound by article 1(1)(b). It would, in other words, apply the Convention only if both parties had their places of business in different contracting states. This reservation was, unfortunately, made by a number of very important states such as China and the United States. It has attracted much scholarly attention and, consequently, some confusion. ${ }^{10}$

What does this reservation mean for contracts between New Zealand as a member state which has not made reservation under article 95 of the CISG and foreign parties, having their place of business in reservation states, for example in China or the United States? Nothing. Despite the reservation declared, these states are contracting states within the meaning of article 1(1)(a), so that the Convention applies on account of this basic provision; article 1(1)(b) and the reservations declared in regard to this provision can be disregarded. This applies whether the case is litigated in New Zealand or in the reservation state.

7 CISG, above n 3, art 1(1)(b)

8 OLG Koblenz, 23 February 1990 CISG-online no 19 <www.cisg-online.ch> (last accessed 26 June 2005).

9 CISG, above n 3, art 95 .

10 See Peter Schlechtriem in Schlechtriem and Schwenzer, above n 2, art 1, paras 42 and 43, art 95, para 4. 
Matters are different if parties in a (contracting) reservation state and in a non-contracting state are involved. If a contract between a Chinese trader - a party having its place of business in a contracting, but reservation state - and a Japanese trader, a party in a non-contracting (a nonConvention) state is at stake, a distinction has to be made. If litigated in a Japanese court under Japanese law, the CISG would not be applicable. If litigated in China under Chinese law, the CISG, although having been ratified by China, would be inapplicable because of the reservation declared by China under article 95 of the CISG. Now, if the case were tried in a New Zealand court and the court's conflict of law rules determined Chinese law as applicable, would that be the CISG? I think that this would not be the case, for the New Zealand court has to apply Chinese law as a Chinese court would do, which would mean the New Zealand court would have to respect China's reservation under article 95 of the CISG by not applying the CISG. ${ }^{11}$

\section{CISG and Conflict of Laws Rules}

Although it was thought by those drafting and promulgating a uniform sales law that it would make conflict of laws rules obsolete, this is not the case. Even if the CISG is applicable on account of article 1(1)(a) - which in itself could be regarded as a one-sided conflict rule there are many questions not covered by the Convention which have to be solved under domestic law determined by conflict rules of the forum. ${ }^{12}$ And in the case of an article 1(1)(b) situation, conflict rules are indispensable, since they are a prerequisite to the application of the Convention. Therefore, even in the case of a sale clearly governed by the Convention, it is advisable to have a choice of law clause.

\section{OPTING OUT AND OPTING IN}

\section{A Opting Out}

When reading the prerequisites of application and realising that the contract of the client might be governed by the Convention, every lawyer must have in the back of his or her mind: can I get out of the Convention, and how? Article 6 provides an answer, but only a partial one.

(a) The parties can opt out of the Convention on the conflict of laws level by choosing the law of a non-contracting state. The New Zealand and the German party to a sales contract can opt out of the CISG by choosing English law to govern their contract. Since England has not enacted the Convention, the CISG is not applicable. Although this is clearly stated in article 6 of the CISG, ultimately it is the conflict of laws rules of the forum that decide such matters as whether such a choice of law clause is valid, how it has to be agreed upon, and whether some form requirement

11 This is controversial, however. Some writers argue that the phrase "the Declaration State is not bound" means that other contracting states, which have not declared this reservation - like New Zealand - are bound by article 1(1)(b) and, therefore, have to apply the Convention, since its conflict rules determine a contracting state's law as applicable. For references see Peter Schlechtriem and Ingeborg Schwenzer, above $\mathrm{n} 2$, art 1, para 42 .

12 See below, part IV. The Scope of the Convention - Part 1. 
applies. ${ }^{13}$ If, for example the choice of law clause is to be found only in a letter of confirmation, the forum state's conflict rules decide whether this choice of law clause is valid.

(b) The parties can also opt out on the level of substantive law. This is the core meaning of article 6 of the CISG. If in a contract between an Australian and New Zealand trader, the CISG would be applicable on account of article 1(1)(a), the parties can derogate from the uniform sales law and opt, for example, for the New Zealand Sale of Goods Act 1908. But there is a catch that has led to a great number of court decisions. ${ }^{14}$ If the clause only reads something like, "the parties stipulate that the law of New Zealand applies to this contract", then, since the CISG is part of the law of New Zealand, the CISG would still govern, at least on the plain meaning of this clause. The parties, therefore, have to make it clear if they want to derogate from the CISG, by stating that the CISG should not apply. Although this could also be derived from the interpretation of a clause not expressly excluding the CISG, the parties are well advised to be clear on this point.

\section{B Opting in}

Opting in can happen on two levels, too. Parties in non-contracting states, for example a trader in England and the counterpart in Japan, can agree that New Zealand law is applicable to their contract. This would mean that under article 1(1)(b) the CISG as the applicable New Zealand law would govern the contract. These cases may arise in particular in arbitration, when parties from noncontracting states have opted for a "neutral law", for example arbitration in Switzerland under Swiss law.

Parties in contracting states can also agree that their contract should be governed by CISG rules despite the fact that it is not a sales contract falling under the Convention. Thus, sales of ships, excluded from the applicability of the Convention under its article 2(e), could be submitted to the CISG. In mixed contracts, where it might be unclear whether the CISG applies, the parties can avoid problems by clearly denominating the rules of the CISG as applicable to the entire contract. There is, however, a limit to this opting in: since opting in on the level of substantive law is a use of party autonomy governed by the applicable domestic law, the limits on party autonomy of this law apply, too. If, for example the parties attempt to escape some consumer protection provision of the applicable law, such as the right to rescind a contract within a certain period of time, by referring to the CISG as applicable law, this would not derogate from mandatory provisions to protect consumers under the applicable domestic law.

13 In European courts, this could be the Rome Convention on the Law Applicable to Contractual Obligations (19 June 1980) 1457 UNTS 6, which in article 8 determines the law applicable to the contract as determining the validity of a choice of law clause, which may lead back to the CISG, articles 14-24.

14 See the references in Schlechtriem and Schwenzer, above $\mathrm{n} 2$, art 6, paras 5 and 14. 


\section{SALE OF GOODS}

\section{A Goods}

The CISG applies only to a sale of goods. Goods are mainly tangible objects. Rights, in particular industrial or intellectual property rights are, in themselves, not goods in the meaning of the Convention. Real estate is not "goods". Certain assets that could be regarded, and which are treated in some jurisdictions, as goods are excluded for different reasons, for example ships, ${ }^{15}$ stocks, shares and negotiable instruments, ${ }^{16}$ and electricity. ${ }^{17}$ In addition, goods bought for personal, family or household use, that is consumer goods, are almost always excluded. ${ }^{18}$ Software is controversial, and there are many distinctions and differentiations advocated, for example whether it is standard or custom-made software, whether software is tangibly embodied in discs or hard drives, or whether it is to be delivered, that is, transmitted electronically for downloading by the recipient, whether the acquired software could be used forever or only temporarily (with a right of renewal). I believe that software acquired forever and inheritable from the first acquirer to its heirs should be treated as goods and fall under the Convention with appropriate accommodation of its provisions. If, however, software can be used only for a certain period of time, and the use can be revoked for example by an administrator in insolvency, the contract is a licence contract not governed by the sales law. ${ }^{19}$

Goods to be manufactured are also governed by the Convention. ${ }^{20}$ However, there is an uncertain borderline between sales and services (contracts for work) in cases of objects to be produced or altered, in particular, when the client (that is the presumptive buyer) supplies all or a great part of the materials: is it a manufacture of goods to be delivered like pre-existing goods sold, or is it simply a processing of the client's materials? Article 3(1) attempts to draw the line according to who supplied the more substantial part of the materials used for the manufacture: if the party who orders the goods supplies a substantial part of the material for the manufacture or production of the goods, it is no longer a sale falling under the Convention. Thus, in an Austrian case, ${ }^{21}$ an Austrian

15 CISG, above n 3, art 2(e).

16 CISG, above n 3, art 2(e)

17 CISG, above n 3, art 2(f).

18 As to the exception, where the intended consumer use was unknown and not discernible for the seller, see CISG, above n 3, art 2(a).

19 See Schlechtriem and Schwenzer, above n 2, art 1, para 21a. See also Frank Diedrich "Maintaining Uniformity in International Uniform Law via Autonomous Interpretation: Software Contracts and the CISG" (1996) 8 Pace Int'l L Rev 303.

20 CISG, above n 3, art 3(1).

21 Oberster Gerichtshof 1 (Austrian Supreme Court), 24 October 1954 CISG-online no 133 <www.cisgonline.ch> (last accessed 26 June 2005). 
firm had brooms produced by a firm in former Yugoslavia from materials mostly supplied by the Austrian party - the economic background being, of course, that labour was much cheaper in Yugoslavia. This was not a sales contract under the Convention, but a service contract to process the material supplied. But there are many problems in interpreting this provision, for example what constitutes substantial (value, or essential function as in case of computer chips supplied by the client?), what about the labour costs of manufacturing - are they part of the equation, ${ }^{22}$ are designs, patents, and the like provided by one or the other part materials?

\section{B Sales}

Sales means an exchange of goods for money. Barter contracts are not sales. Certain sales are excluded, for example auctions, because at the time of the drafting of the Convention auctions were held only locally and rarely across borders. This has changed, however, and it stands to be argued whether article 2(b) should not be limited to local auctions, thus allowing electronic transborder auctions to be governed by the CISG.

However, the Convention goes beyond mere sales: Article 3(2) mandates its application to mixed contracts, where one party has undertaken not only to deliver goods, but also to provide services, for example where the seller of an assembly line has contracted to install the assembly line at the purchaser's factory, ${ }^{23}$ where the equipment for a window-production plant is sold and the seller, in addition, has to erect the plant, ${ }^{24}$ or where a special machine is sold and the seller has promised to install the electronic guidance control system of the machine. ${ }^{25}$ If these different obligations are part of one contract, such as where there is a lump sum price for the whole transaction, the mixed contract has to be qualified entirely either as a sale or a service contract, or it has to be split. The CISG has opted for treating it as a unitary contract, being governed by the CISG only if the preponderant part of the transaction is the delivery of goods. Again, this provision, inserted without much thought for its consequences, raises numerous problems. First of all, preponderant (as is substantial in article 3(2) paragraph 2) is open to different understandings. ${ }^{26}$

22 Kreisgericht Bern-Lampen, 29 January 1999 CISG-online no 701 <www.cisg-online.ch> (last accessed 26 June 2005), rightly criticised by Frederike Schäfer "Zur Anwendbarkeit des UN-Kaufrecht auf Werklieferungsverträge" Internationales Handelsrecht 2003, 118-21.

23 ICC International Court of Arbitration, 7660 of 1994 CISG-online no 129 <www.cisg-online.ch> (last accessed 26 June 2005)

24 OlG München, 3 December 1999 CISG-online no 585 <www.cisg-online.ch> (last accessed 26 June 2005), with a note by Ulrich Schroeter "Vienna Sales Convention: Applicability to 'Mixed Contracts' and Interaction with the 1968 Brussels Convention" (2001) 5 Vindobona Journal of International Commercial Law and Arbitration 74 and following.

25 Compare the facts of the case decided by the BGH (German Supreme Court), 31 October 2001 CISG-online no $617<$ www.cisg-online.ch> (last accessed 28 September 2005).

26 See CISG Advisory Council "Contracts for the Sale of Goods to be Manufactured or Produced and Mixed Contracts (Article 3 CISG)" CISG-AC Opinion 4 <www.cisg.law.pace.edu> (last accessed 18 June 2005). 
Second, and more importantly, it is very uncertain what the consequences are in a case of a breach of the service obligations under the contract. Are the remedies of the Convention to be applied with appropriate modifications? What are these modifications?

\section{THE SCOPE OF THE CONVENTION - PART I}

Article 4 circumscribes in its first sentence the scope of issues governed by the Convention as "formation of the contract" and "rights and obligations [of the parties] arising from such a contract". This is, however, only a sketchy introduction.

\section{A Some Extensions}

The Convention also governs the interpretation of communications of the parties and their contracts in article 8 , requiring all circumstances and extrinsic evidence for these interpretations to be taken into account. There is, therefore, no "plain meaning rule" of domestic law applicable to a CISG contract. "Merger clauses" are open to interpretation, too, which might lead to a more restrictive understanding of such a clause than its plain meaning indicates. Article 9 qualifies international usages as applicable, although on account of implied agreements.

Article 11 dispenses with all requirements of form, be they characterised as substantive law or procedural law or as an issue of evidence. There is no room, therefore, for a "parol evidence rule" or a domestic statute of frauds. States could, however, declare a reservation in regard to article 11 thus cancelling freedom of form in favour of domestic form requirements. ${ }^{27}$ It is controversial, however, which domestic law then governs form: the form provisions of the reservation state or the contract form law determined by the conflict of law rules of the forum? The latter is the prevailing view and court practice in Europe. Therefore, in case of a contract between a New Zealand party and a Chinese trader - China having declared a reservation under article 96 to the effect that article 11 will not apply - it has to be asked which law governs the form of contracts under the conflict of laws rules of the forum. It is advisable to have a clear agreement on this in the contract itself.

\section{B Exclusions}

All matters not covered by the formula of article 4 sentence 1 (and possible extensions by interpretation and gap-filling, as discussed below) are meant to be excluded from the Convention and have to be dealt with in applying domestic law as determined by the conflict of laws rules of the forum. Article 4 sentence 2 lists, as examples two particular important areas:

First of all, validity of the contract or of any of its provisions "is outside the scope of the Convention". ${ }^{28}$ This exclusion covers a wide range of issues from capacity of persons to agency, mistakes voiding a contract and, in particular, domestic or international regulations prohibiting

27 Compare CISG, above $\mathrm{n}$ 3, arts 12 and 96. 
certain sales, such as embargos or restrictions on the export of goods such as arms, nuclear material and the like. If a state licence is required for certain contracts and it is denied by the competent administrative authorities in a given case, this is a validity issue governed by domestic law, too.

Equally important is the second exclusion in article 4 sentence 2(b): the effect of the contract on the property in the goods sold. The drafters did not - and could not - draft uniform rules on the transfer of property and whether it takes place solo consensus - by mere conclusion of the sales contract - or only at delivery. But the exclusion of all property questions extends to security interests as well. Thus, when a contract between an Australian buyer and a German seller contained a title reservation clause, amounting to a security interest granted to the seller, the Australian Court correctly held that the effects of a retention of title clause, preventing the passing of property, was governed not by the Convention but by the law applicable to property, being - under Australian conflict rules - German law. ${ }^{29}$

\section{Interpretation and Gap-Filling}

No codification is ever perfect, and every legal text, therefore needs instruments and concepts that allow adjustments, development and gap-filling to cope with issues not foreseen by its drafters. This is even more so in the case of codifications based on international conventions, for, while a domestic legislator might be willing and competent to enact necessary improvements and reforms, the chances that another United Nations conference can be convened on the CISG, that it will reach results, and that all states that have enacted the Convention will also enact reforms, is almost zero. So there must be safety valves. They are interpretation and gap-filling. The basis is article 7 of the CISG, the formulation of which can now be found in a number of other international conventions, model laws and drafts. ${ }^{30}$

Article 7(1) of the CISG lays down rules on interpretation of the Convention. Interpretation of an international convention is different from interpretation of domestic legislation, since ambiguities of words and concepts cannot be cleared up by having recourse to other sectors of the same legal system. There are three directives for the interpretation of the Convention to be found in article 7(1):

(i) Article 7(1) states that - first of all - regard is to be had to the international character of the Convention. This is the principle of autonomous interpretation. The Convention has to be interpreted exclusively on its own terms. In reading and understanding the provisions, concepts and

29 Roder Zelt- und Hallenkonstruktionen GmbH v Rosedown Park Pty and Reginald Eustace (1995) 57 FCR 216,240 (FCA).

30 See for example, Convention on Agency in the International Sale of Goods (17 February 1983) 22 ILM 249, art 6(1); UNIDROIT Convention on International Factoring (28 May 1988) 27 ILM 943, art 4(1); UNIDROIT Convention on International Financial Leasing (28 May 1988) 27 ILM 931, art 6(1); UN Convention on the Assignment of Receivables in International Trade (12 December 2001) 41 ILM 776, art $7(1)$. 
words of the Convention, recourse to the understanding of these words and the like in domestic systems, in particular in the domestic legal system of the reader, must be avoided. This seems to be self-evident, but experience shows that practitioners and scholars tend to understand words and concepts of the Convention according to their familiar domestic law.

(ii) Further, article 7(1) requires consideration of the need to promote uniformity in the application of the Convention. This, at first sight, looks innocuous, but in my opinion, it is the basis for a kind of international recognition of precedents, that is respecting decisions from all contracting states, if not fully binding as under a doctrine of stare decisis, but as a persuasive authority. There are already examples for this, such as where a United States court thoroughly analysed a decision of the German Supreme Court, following its basic rule, but distinguished the case at hand from the facts of the German case. ${ }^{31}$ This - the taking account of foreign courts' judgments - is facilitated by a number of electronic databases offering access to decisions from all contracting states, often translated into English. ${ }^{32}$

(iii) Thirdly, article 7(1) mentions the observance of good faith in international trade. This is a much disputed phrase, and, in my opinion, it is often misunderstood. First of all, it only applies to the interpretation of the Convention, although a great number of legal writers advocate applying it to contractual agreements as well. ${ }^{33}$ Secondly, one has to avoid falling prey to preconceptions caused by domestic rules such as the German good faith and fair dealing concept, which became the most important tool for adapting the German Civil Code to new challenges. Good faith in international trade, instead, has to be analysed autonomously by taking into account practices, standard forms, value judgments of courts and arbitration tribunals in international cases as forming a body of law merchant beyond the written text of conventions.

The interpretation of provisions of the CISG under article 7(1) can cause them to be slightly extended, even amended to cover issues not foreseen by the drafters of the Convention. For example, the question of when electronic communications become effective - such as the withdrawal of an offer, ${ }^{34}$ the revocation of an acceptance, ${ }^{35}$ and the objection to a late acceptance ${ }^{36}$

31 See Medical Marketing v Internazionale Medico Scientifica 1999 WL 311945 (EDLa), CISG-online no 387 $<$ www.cisg-online.ch> (last accessed 26 June 2005).

32 See Case Law on UNCITRAL Texts (CLOUT) <www.uncitral.org > (last accessed 26 June 2005); UNILEX <www.unilex.info> (last accessed 26 June 2006); Pace Law School <http://law.pace.edu/cisg > (last accessed 26 June 2006); CISG-online <www.cisg-online.ch $>$.

33 For references see Peter Schlechtriem in Schlechtriem and Schwenzer, above n 2, art 7, para 6.

34 CISG, above n 3, arts 15(2) and 24

35 CISG, above n 3, art 22. 
- can be solved by interpretation of the respective provisions. Recourse to domestic law is not necessary and should be avoided.

If interpretation fails to adjust the Convention, gap-filling under article 7(2) has to be considered. There are two steps to fill a gap. First and foremost, a uniform rule based on general principles, on which the Convention is based, should be searched for and formulated. Second, but only if gap-filling by a uniform rule fails, recourse is to be had to domestic law denominated by the conflict of law rules of the forum. The problem of the first step is obvious. What and where are the general principles of the Convention? It does not state them explicitly. Therefore, they have to be derived from an analysis of concrete provision so to unearth the general principles underlying them. Thus, from a number of provisions one can derive the general principle of estoppel; ${ }^{37}$ or a number of provisions allow withholding one's own performance until the other party has performed or has provided adequate assurance of its performance. ${ }^{38}$ This makes it possible to formulate a general right to retain one's own performance until the other party has fulfilled its part of the contract. ${ }^{39}$ On the other hand, where no principle can be found, gap-filling by uniform rules is impossible, and one has to revert to domestic law. For example, rules on set-off or assignment of receivables differ widely in domestic systems, and no uniform principle can be found in the CISG as to prerequisites and operation of set-off or assignments. Therefore, recourse to domestic law is unavoidable in most cases. $^{40}$

\section{THE SCOPE OF THE CONVENTION - PART II}

Although I cannot deal with the contents of the Convention in detail, I shall try to sketch its basic structure, for I am convinced that its success is due at least in part to the simplicity of this structure, which allows easy access even for the uninitiated. While Part I of the Convention lays down the prerequisites of application dealt with in the preceding section, Part II deals with the formation of contracts, following traditional patterns of offer and acceptance. Placed in Part III, but belonging to Part II, article 29 is the provision on modification and termination of the contract by agreement, allowing for example partial releases without consideration. It also governs, in my

37 See CISG, above n 3, arts 16(2)(b) and 29(2) sentence 2.

38 See CISG, above n 3, arts 58(1), 71 and 81(2) sentence 2.

39 For an extensive discussion see Peter Schlechtriem in Schlechtriem and Schwenzer, above n 2, art 7, para 34.

40 That is, unless instruments such as the UNIDROIT-Principles of International Commercial Contracts (see above $\mathrm{n}$ 2), which contain explicit provisions on set-off (articles 8.1 - 8.5) and assignment (articles 9.1.1 9.1.15) can be qualified as usages applicable under article 9 of the CISG. 
opinion, questions such as an attempted amendment of a contract to insert a jurisdiction clause by way of invoices sent by the seller and paid for without objection by the buyer. ${ }^{41}$

Part III, the core of the Convention, regulates the rights and remedies of the parties, and it is easy to understand, basically because it first states the obligations of the seller and the remedies of the buyer in case of breach, and then, vice versa, the obligations of the buyer and the respective remedies of the seller. Some parties state general provisions applicable to both parties, notably the provisions on damages. The backbone of the legal relation between the parties are the remedies, notably the claim for damages and the right to avoid - that is terminate - the contract. Although a claim for specific performance is part of this backbone, too, common law courts do not have to grant specific performance, unless they would do so under their own domestic law. ${ }^{42}$ A Roman Law inheritance much disliked by many common law jurists, is the price reduction by the buyer in case of non-conforming goods. Also, common law jurists complain that a perfect tender rule is missing, so that, seemingly, a buyer has to take over non-conforming goods and claim damages or price reduction, unless the non-conformity is so serious as to amount to a fundamental breach, allowing avoidance and, consequently, rejection of the goods. This problem can be taken care of, however, by a general right to withhold performance, which I have mentioned before. ${ }^{43}$

The most important remedy is, of course, the obligee's claim for damages in case of breach. The respective rules should be familiar to common law jurists. But there is one notable exception and, as a consequence, an argument among legal writers about its extent. Article 5 excludes from the Convention actions and claims for personal injuries and death caused by the goods. This was due to the general products liability issue emerging in the 1960s and producing new rules of strict liability, with which the drafters of the Convention did not want to interfere. But there are problems, which were overlooked. First, since mixed contracts might be governed by the CISG too, on account of article 3(2), it can be debated whether personal injury or death not caused by the goods, but by malperformance of services, is governed by the Convention. To my mind, they should not be governed by the Convention, and article 5 should be interpreted accordingly.

More difficult is the problem of consequential - or "special" damages - in the form of injury to property caused by defective goods, for example a fire caused by a shortcircuit in a machine sold, which destroys the purchaser's plant. Certainly, the buyer must have a damage claim under the Convention, if such damages were in the contemplation of the parties, since article 5 does not extend

41 Compare the United States case Chateau des Charmes Wines Ltd v Sabaté USA Inc, Sabaté SA (2003) 328 F $3 \mathrm{~d} 528$ (9th Cir) which correctly denied effect to such a clause printed on the invoice, although the reasoning of the Court is slightly off track.

42 CISG, above n 3, art 28.

43 For details see Peter Schlechtriem "CISG - Interpretation, Gap-Filling and Development" (English translation) (Symposium für Frank Vischer, Basel, 2004) CISG-online <www.cisg-online.ch $>$ (last accessed 15 June 2005). 
to property damages. But does the Convention exclusively govern, or can the purchaser invoke tort liability under domestic law, that is file a concurrent action? The importance of this point is obvious in cases where the buyer has lost his or her claim under the Convention for having neglected to give notice of the known or discoverable defects within a reasonable period of time, ${ }^{44}$ or if the fire has occurred more than two years after delivery, so that rights and remedies of the buyer are barred by the two-year limit of article 39(2). I advocate the opinion that concurrent actions are not excluded by the Convention, but there are a number of legal writers who hold the opposite view. ${ }^{45}$

\section{TWO EXAMPLES}

When the great scholar John Honnold defended the Convention before the subcommittee of the United States Senate which was in charge of preparing the decision of the Senate on the CISG's ratification, he - as he later told me - remarked something along the following lines: in evaluating the Convention, you should not compare it with the Uniform Commercial Code (UCC) and should not ask, whether it is better than or inferior to the UCC. Certainly, the UCC is better for American parties and their counsel and lawyers. But you should ask, whether the CISG is better and easier to apply than, for example, the sales law of Mongolia or China. For we cannot expect that the UCC will always apply to international sales and that foreign parties will always submit to American law. ${ }^{46}$

Two cases tried by an arbitration tribunal of the International Chamber of Commerce in Paris, in which I was involved, may illustrate his point.

In the first case, a French manufacturer of computers had sold a computer system to a Russian bank for handling its international money transactions; it consisted of hardware and software. The seller was in delay in installing the software, and the Russian party after having twice set an additional period of time finally declared termination of the entire contract (the background being that the bank had merged with another bank, which was already equipped with all the computers needed). A choice of law clause determined Russian law as applicable. Both parties presented expert witnesses testifying on Russian law in general and the prerequisites of termination in particular. Three law professors testified that under the Russian Civil Code termination would not be allowed under the facts of the case, and three law professors testified to the contrary. What should the

44 CISG, above n 3, arts 38 and 39(1).

45 See, for example, Martin Köhler Die Haftung nach UN-Kaufrecht im Spannungshälnis zwischen Vertrag und Delikt (Mohr Siebeck, Tübingen, 2003) 142 and following; Rolf Herber "Mangelfolgeschäden nach dem CISG und nationales Deliktsrecht" Internationales Handelsrecht 2001, 187 and following; Dirk Schneider UN-Kaufrecht und Produkthaftpflicht (Helbing und Lichtenhalm, Basel, 1995).

46 Told by John Honnold to author during a discussion about CISG issues. 
tribunal do? Fortunately, the CISG was able to be applied as part of the Russian law, ${ }^{47}$ and it provided a firm ground for decision.

In another case a cotton mill was sold to a firm in Turkmenistan, but it was never delivered. Again, a choice of law clause determined Russian law as applicable. The issue was one of calculating recoverable damages, in particular, whether lost profits from the expected product of the cotton mill could be claimed. Again, the tribunal did not know enough about Russian domestic law, and would have had to rely on expert witnesses. But articles 74 and 75 of the CISG were, if not familiar, easy to understand with the help of commentaries, precedents and contributions of legal writers and therefore provided a solid basis for deciding the damages issues. ${ }^{48}$

I could go on with examples like that. They not only show that the CISG facilitates the resolution of international disputes arising from sale of goods contracts, but also that it can make such conflicts less expensive for the parties, reducing the number of experts, interpreters, paralegals, and the like, needed. It may also result in a reduction of billing hours of the law firms involved, and this, therefore, should be the moment to stop my praise of the CISG in front of an audience of practitioners!

47 The problem was whether the software part of the contract prevented application of the Sales Convention.

48 The questions of the applicability of the CISG turned upon the turnkey-character of the contract. 